Zeszyty Naukowe Szkoły Głównej Gospodarstwa Wiejskiego w Warszawie Problemy Rolnictwa Światowego tom 17 (XXXII), zeszyt 3, 2017: 308-318

DOI: 10.22630/PRS.2017.17.3.76

Krystyna Zarzecka $^{1}$, Agata Grużewska ${ }^{2}$, Marek Gugala ${ }^{3}$, Anastasiia Yatsyshyn ${ }^{4}$

1,2,3 Uniwersytet Przyrodniczo-Humanistyczny w Siedlcach

${ }^{4}$ Państwowa Szkoła Wyższa im. Papieża Jana Pawła II w Białej Podlaskiej

\title{
Produkcja i jakość ziemniaka jadalnego w opinii konsumentów w Polsce i na Ukrainie
}

\section{Production and Quality of Table Potato in the Opinion of Consumers in Poland and Ukraine}

\begin{abstract}
Synopsis. W pracy przedstawiono wyniki badań ankietowych, przeprowadzonych metodą wywiadu bezpośredniego w 2014 roku na terenie Ukrainy, w mieście Łuck i Polski, w mieście Biała Podlaska. W badaniach uczestniczyło 100 osób pochodzących po połowie z Ukrainy i Polski. Kwestionariusz ankietowy zawierał dwanaście pytań, w tym dziesięć pytań zamkniętych i dwa, w których trzeba było wybrać 2-3 warianty odpowiedzi. Badania przeprowadzono anonimowo, uwzględniając pięć przedziałów wiekowych respondentów. Analiza udzielonych odpowiedzi wskazała, że większość ankietowanych uprawiało ziemniak w swoim gospodarstwie. W Polsce największa liczba respondentów stwierdziła, że spożywają bulwy ziemniaka 1-2 razy w tygodniu, mieszkańcy Ukrainy preferowali spożywanie 3-4 razy w tygodniu, a preferowaną formą w obu krajach były ziemniaki gotowane z wody. Bulwy do celów konsumpcyjnych pochodziły z własnej produkcji oraz kupowane były głównie na bazarze. Większość ankietowanych Polaków interesowała się krajem pochodzenia kupowanych ziemniaków oraz etykietą na opakowaniu. Na decyzje zakupowe mieszkańców Ukrainy wpływała głównie cena, a opakowanie miało najmniejsze znaczenie. Ankietowani pochodzący z obu krajów najbardziej doceniali w ziemniaku dobre walory smakowe, ponadto oczekiwali bulw o dobrej jakości kulinarnej i o dobrym wygladzie zewnettrznym. Zdecydowanie mniejsze wymagania ankietowanych dotyczyły „bogatej” w informacje etykiety i przystępnej ceny.
\end{abstract}

Słowa kluczowe: ziemniak, spożycie, produkcja, preferencje konsumenckie

Abstract. The paper presents results of survey research conducted in Łuck (Ukraine) and Biała Podlaska (Poland) in 2014. A total of 100 people, half of them Polish and the other half Ukrainian, were interviewed in the study. They were asked twelve questions, including ten open-ended questions and two questions which had 2-3 answers to choose from. The survey was anonymous and was carried out in five age groups. Analysis of the answers demonstrated that most respondents grew their own potatoes. The majority of Polish respondents said they consumed potatoes once or twice per week, Ukrainians eating them three or four times per week. In both countries, the preferred consumption form was boiled potatoes. Tubers for consumption were produced by the respondents or were purchased, mainly at the market. The majority of Poles wanted to know the country of origin of the potatoes they wanted to buy. Also, they were interested in the label attached to the package of the potatoes. Ukrainians predominantly made their decisions based on the price, the labelling being the least important. Respondents from both countries paid the greatest attention to potato flavour; they expected potatoes to be characterised by good cooking quality and appealing external appearance. They were by far less interested in an informative label and affordable price.

Key words: potato, consumption, production, consumer preferences

${ }^{1}$ prof. dr hab., UPH w Siedlcach, Katedra Agrotechnologii, ul. B. Prusa 14, 08-110 Siedlce,

e-mail: krystyna.zarzecka@uph.edu.pl

${ }^{2}$ dr hab., UPH w Siedlcach, Zakład Ekonomiki Rolnictwa i Agrobiznesu, ul. B. Prusa 14, 08-110 Siedlce,

e-mail: agata.gruzewska@uph.edu.pl

${ }^{3}$ dr hab., UPH w Siedlcach, Katedra Agrotechnologii, ul. B. Prusa 14, 08-110 Siedlce,

e-mail: marek.gugala@uph.edu.pl

${ }^{4}$ inż., Państwowa Szkoła Wyższa w Białej Podlaskiej, Katedra Nauk o Środowisku, ul. Sidorska 95/97,

21-500 Biała Podlaska, e-mail: anastasiiayatsyshyn94@gmail.com 


\section{Wprowadzenie}

Ziemniak (Solanum tuberosum L.) jest jedną z ważniejszych roślin uprawianych w Polsce, Europie i na świecie. Ma on duże znaczenie konsumpcyjne, przemysłowe, paszowe, a także płodozmianowe. Jest coraz bardziej doceniany i zalecany w jadłospisie, dominuje jako roślina jadalna. Odmiany bardzo wczesne i wczesne zaliczane są do roślin warzywnych, a średnio wczesne, średnio późne i późne do roślin rolniczych. Specjaliści od żywienia twierdzą, że wartość odżywcza ziemniaka jest tak duża, że może on być jedynym pożywieniem człowieka przez pewien czas, bez uszczerbku dla zdrowia (Kunachowicz i in., 2010; Stypa i Zgórska, 2010). Bulwy Solanum tuberosum są zdrowe, smaczne i tanie, jednocześnie dostępne przez cały rok, a ponadto łatwe w przygotowaniu do bezpośredniej konsumpcji, a sporządzane $\mathrm{z}$ nich potrawy są zalecane dla najmłodszych i najstarszych (Stypa i Zgórska, 2010; Wierzbicka, 2012; Zarzecka, 2009).

W skali światowej około 80 tysięcy gatunków roślin wyższych jest wykorzystywanych jako pokarm dla ludzi i pasza dla zwierząt. Jednak tylko 150 gatunków jest uprawianych na cele żywnościowe. Ponadto należy podkreślić, że tylko około 30 gatunków roślin pokrywa aż w 95\% potrzeby białkowe i kaloryczne organizmu człowieka. Z tej liczby najważniejsze w świecie od wielu lat są cztery rośliny: pszenica (Triticum ssp), ryż (Oryza sativa), kukurydza (Zea mays), ziemniak (Solanum tuberosum) (Stypa i Zgórska, 2010). Ziemniak pod względem powierzchni uprawy i zbiorów zajmuje czwarte miejsce w świecie, stąd ma duże znaczenie w wyżywieniu ludności świata. Jest uprawiany w $160 \mathrm{krajach}, \mathrm{tj}$. w ponad 80\% wszystkich państw (Camire i in., 2009; Sołtys 2013; Zarzecka i in., 2013; Zhu i in., 2010). Od ponad dziesięciu lat Europa przestała dominować w produkcji ziemniaka, a największy areał uprawy i zbiory odnotowuje się na kontynencie azjatyckim (Rynek ziemniaka..., 2016).

Celem pracy było przedstawienie znaczenia gospodarczego ziemniaka oraz zobrazowanie wiedzy o jakości bulw, formach spożycia, cechach decydujących o zakupie i oczekiwaniach konsumenta w Polsce i na Ukrainie.

\section{Produkcja ziemniaka w Polsce i na Ukrainie}

W latach 70 ubiegłego wieku ziemniak w Polsce zajmował powierzchnię około $3 \mathrm{mln}$ ha $\mathrm{z} 18 \%$ udziałem tego gatunku w strukturze zasiewów. Następnie areał uprawy systematycznie się zmniejszał i według danych IERiGŻ-PIB i IHAR-PIB i w 2016 roku wynosił 307 tys. ha, co stanowiło 2,8\% ziemniaka w strukturze zasiewów i aż 16,1\% powierzchni tej rośliny w całej UE (28 krajów). Ograniczanie areału uprawy ziemniaka wynikało przede wszystkim $\mathrm{z}$ rezygnacji wykorzystywania bulw na paszę oraz w gorzelnictwie, a także uwarunkowań ekonomicznych (Grużewska i in., 2016; Rynek ziemniaka..., 2015, 2016). W 2015 roku odnotowano zahamowanie zmniejszania się powierzchni uprawy. Nastąpiła rezygnacja z uprawy ziemniaka w gospodarstwach mniejszych obszarowo, a postępowała koncentracja i specjalizacja gospodarstw dużych, uprawiających tę roślinę na konsumpcję bezpośrednią - bulwy konfekcjonowane, do przetwórstwa spożywczego i przemysłu skrobiowego (Nowacki, 2015, 2016). W krajach UE dominującą pozycję pod względem powierzchnii uprawy ziemniaka, plonów i zbiorów zajmują: Niemcy, Francja i Holandia. Kraje te charakteryzują się stabilizacją zbiorów, 
a niewielki spadek powierzchni uprawy jest kompensowany rosnącymi plonami (Rynek ziemniaka..., 2016).

Plony bulw ziemniaka w Polsce, $w$ ostatnich dziesięcioleciach oscylowały w przedziale 16-20 ton/ha, z tendencją niewielkiego wzrostu. Od 2010 roku, gdy redukcji ulegać zaczęła liczba gospodarstw uprawiających ziemniak, plony zwiększały się, w 2014 roku nawet do 27,8 t/ha i w 2016 do 29,7 t/ha. Były jednak nadal ponad dwa razy mniejsze niż otrzymywane w doświadczeniach w COBORU i mniejsze niż średnie w krajach UE-28, gdzie przekraczały 33 t z 1 ha. Do krajów UE wyróżniających się pod względem wielkości plonów, wynoszących 41-50 t/ha należą: Belgia, Holandia, Francja, Niemcy (Lista opisowa odmian, 2015; Rynek ziemniaka..., 2016).

$\mathrm{Na}$ przestrzeni ostatnich lat zmniejszyła się konsumpcja ziemniaka oraz forma sprzedaży. Traciła na znaczeniu sprzedaż targowiskowa, a oferta handlowa sieci sklepowych stawała się coraz bogatsza pod względem odmian, wielkości i rodzaju opakowań oraz stopnia przygotowania bulw do sprzedaży (Nowacki, 2016). W latach 60. ubiegłego wieku jego spożycie było wysokie, przekraczało nawet $200 \mathrm{~kg}$ na 1 osobę na 1 rok (Herse, 1980). W ostatnich latach 2015-2016 spożycie wynosiło 100-101 kg na 1 mieszkańca, dominowały ziemniaki nieprzetworzone ( $81,8 \mathrm{~kg} / 1$ mieszkańca) (tab. 1).

Tabela 1. Powierzchnia uprawy, plony, zbiory i spożycie ziemniaka w Polsce, w latach 1999-2016

Table 1. Area cultivation, yields, production and consumption of potato in Poland in the years 1999-2016

\begin{tabular}{c|cccc}
\hline Lata & $\begin{array}{c}\text { Powierzchnia } \\
\text { uprawy, tys. ha }\end{array}$ & Plony, t/ha & Zbiory, mln t & $\begin{array}{c}\text { Spożycie, kg na 1 mieszkańca } \\
\text { rocznie }\end{array}$ \\
\hline 1999 & 1268 & 15,7 & 19,93 & 135 \\
2000 & 1250 & 18,2 & 22,75 & 131 \\
2001 & 1030 & 18,0 & 18,53 & 134 \\
2002 & 921 & 19,0 & 17,48 & 131 \\
2003 & 815 & 17,9 & 14,57 & 131 \\
2004 & 720 & 19,4 & 13,95 & 130 \\
2005 & 590 & 17,6 & 10,40 & 129 \\
2006 & 600 & 15,0 & 9,00 & 126 \\
2007 & 570 & 20,7 & 11,80 & 121 \\
2008 & 550 & 19,1 & 10,50 & 121 \\
2009 & 490 & 18,9 & 9,20 & 118 \\
2010 & 401 & 21,1 & 8,45 & 116 \\
2011 & 406 & 23,0 & 9,36 & 110 \\
2012 & 373 & 24,2 & 9,04 & 111 \\
2013 & 346 & 21,0 & 7,29 & 111 \\
2014 & 277 & 27,8 & 7,70 & 102 \\
2015 & 300 & 21,7 & 6,68 & 101 \\
2016 & 308 & 29,7 & 9,12 & 100 \\
\hline
\end{tabular}

Źródło: obliczenia własne na podstawie danych GUS i IERiGŻ-PIB (Wynikowy szacunek..., 2015; Rynek ziemniaka..., 1998-2016).

Całkowita powierzchnia upraw rolniczych na Ukrainie w 1990 roku wynosiła 32406 tys. ha, następnie zmniejszała się do 27258 tys. ha w 2014 r. Według danych Państwowej Służby Statystyki Ukrainy areał uprawy ziemniaka w 1990 roku wynosił 1429 tys. ha, a do 2000 roku uległ zwiększeniu do 1600 tys. ha (tab. 2). Od 2002 roku areał ulegał zmniejszeniu 
do 2014 roku, do poziomu poniżej 1300 tys. ton. Mimo znacznej powierzchni zasiewów i zbiorów bulw Ukraina nie eksportowała ziemniaka i znaczna część plonu podlegała stratom w wyniku niewystarczającej ochrony przed szkodnikami i podczas nieprawidłowego przechowywania. W 2014 ziemniak zajmował w strukturze zasiewów 5\% upraw (Statystyczny Rocznik Ukrainy, 2015). Według danych FAO, w 2014 roku Ukraina należała do największych producentów ziemniaka $(23,7 \mathrm{mln}$ ton ziemniaka na powierzchni $1,3 \mathrm{mln}$ ha).

Produkcja ziemniaka na Ukrainie w 97\% koncentrowała się w gospodarstwach indywidualnych i wykorzystywana była na własne potrzeby. Brak dobrze rozwiniętej produkcji nasiennej ziemniaka sadzeniaka sprzyja rozprzestrzenianiu się chorób i szkodników (Рудь i in., 2015). Dlatego średnie plony bulw ziemniaka na Ukrainie były w badanym okresie stosunkowo niskie - 13,1 t/ha, znacznie mniejsze niż w Europie i Polsce (Statystyczny Rocznik Ukrainy, 2015). W analizowanym okresie najmniejsze plony stwierdzono w 1999 roku (jedynie ok. 8 t z ha), a największą wartość cechy w 2014 roku niemal $18 \mathrm{tz} 1$ ha (tab. 2).

Tabela 2. Powierzchnia uprawy, plony, zbiory i spożycie ziemniaka na Ukrainie w latach 1999-2015

Table 2. Area cultivation, yields, production and consumption of potato in Ukraine in the years 1999-2015

\begin{tabular}{l|cccc}
\hline Lata & $\begin{array}{c}\text { Powierzchnia uprawy, } \\
\text { tys. ha }\end{array}$ & Plony, t/ha & Zbiory, mln t & $\begin{array}{c}\text { Spożycie, kg na } 1 \\
\text { mieszkańca rocznie }\end{array}$ \\
\hline 1999 & 1552 & 8,20 & 12,72 & 122 \\
2000 & 1629 & 12,20 & 19,84 & 124 \\
2001 & 1604 & 10,80 & 17,34 & 133 \\
2002 & 1590 & 10,40 & 16,62 & 121 \\
2003 & 1585 & 11,60 & 18,45 & 118 \\
2004 & 1556 & 13,30 & 20,76 & 120 \\
2005 & 1514 & 12,80 & 19,46 & 118 \\
2006 & 1464 & 13,30 & 19,47 & 102 \\
2007 & 1453 & 13,10 & 19,10 & 101 \\
2008 & 1413 & 13,90 & 19,55 & 98 \\
2009 & 1409 & 13,90 & 19,67 & 90 \\
2010 & 1408 & 13,20 & 18,71 & 93 \\
2011 & 1439 & 16,80 & 24,25 & 91 \\
2012 & 1440 & 16,10 & 23,25 & 88 \\
2013 & 1388 & 16,00 & 22,26 & 82 \\
2014 & 1348 & 17,60 & 23,69 & brak danych \\
\hline 1 & 1291 & 16,10 & 20,84 & 98 \\
\hline
\end{tabular}

${ }^{1}$ Wyłączając czasowo okupowane terytorium Autonomicznej Republiki Krym, Sewastopol i części antyterrorystycznej strefy operacyjnej

Źródło: Statystyczny Rocznik Ukrainy 2015, http://www.ukrstat.gov.ua/; Домбровська 2015.

W Polsce najmniejsze plony ziemniaka odnotowano w latach 1999 i 2006 i wynosiły one odpowiednio 15,7 i 15,0 ton, a największe w 2016 roku - prawie 30 ton z 1 ha (tab. 1). W okresie ostatnich 16 lat spożycie bulw ziemniaka na Ukrainie zmniejszyło się ze $122 \mathrm{~kg}$ (na 1 mieszkańca/rok) - w 1999 do 82 kg w 2014 roku. W 2001 roku konsumpcja przekroczyła racjonalną normę spożycia (124 kg/osobę) i osiągnęła poziom $133 \mathrm{~kg}$, natomiast w 2013 mieszkańcy Ukrainy spożywali $88 \mathrm{~kg}$ bulw ziemniaka na osobę (tab. 2). 
Racjonalna norma spożycia to podaż wszystkich makro- i mikroskładników w ilości odpowiadającej aktualnemu zapotrzebowaniu organizmu człowieka. Zgodnie z zaleceniami żywieniowymi dzienne zapotrzebowanie energetyczne zdrowego dorosłego człowieka powinno być pokrywane w 50-65\% z węglowodanów, w 25-30\% z thuszczów i w 10-15\% z białka (Gawęcki i Hryniewiecki, 2010; Zgórska, 2013b). Spożycie ziemniaka w Polsce było znacznie większe, ale również miało tendencję malejącą od $135 \mathrm{~kg}$ do $100 \mathrm{~kg}$ na 1 mieszkańca rocznie (tab. 1).

\section{Materiał i metody badań}

W publikacji wykorzystano wyniki badań autorskich. Podstawowym narzędziem badawczym był kwestionariusz wywiadu bezpośredniego, przeprowadzonego w 2014 roku na terenie Ukrainy w mieście Łuck i Polski w mieście Biała Podlaska, które wybrano losowo na terenie wschodniej Polski i zachodniej Ukrainy. W badaniach uczestniczyło 100 osób pochodzących po połowie z Ukrainy i Polski. Każda osoba ankietowana była poinformowana o celu badań i została poproszona o wyrażenie zgody na uczestnictwo w nich, jednocześnie pytano, czy konsumuje ziemniaki. Respondenci odpowiadali na dwanaście pytań zawartych w kwestionariuszu ankietowym, w tym dziesięć pytań zamkniętych i dwa, w których trzeba było wybrać 2-3 warianty odpowiedzi. Badania przeprowadzono anonimowo, uwzględniając pięć przedziałów wiekowych.

Kwestionariusz ankietowy zawierał pytania dotyczące kraju zamieszkania, wieku, płci, miejsca zamieszkania, uprawy ziemniaka w gospodarstwie, częstotliwości spożywania ziemniaków w gospodarstwie, formy spożywania bulw, miejsca zakupów, kryteriów wyboru przy zakupie oraz preferencji dotyczących bulw.

Wśród ankietowanych osób najliczniejszą grupę stanowiły osoby w wieku 21-30 lat (35\%) z Ukrainy oraz w wieku 18-20 (40\%) z Polski. Nie stwierdzono osób w wieku powyżej 55 lat. Udział kobiet $\mathrm{w}$ badaniu był większy na Ukrainie (60\%) niż w Polsce $(40 \%)$. Mieszkańcy miasta stanowili 55\% na Ukrainie i 35\% w Polsce, pozostali pochodzili ze wsi.

Wyniki badań poddano analizie statystycznej z wykorzystaniem testu chi-kwadrat, uwzględniając podklasy o liczebności co najmniej wynoszącej 10 odpowiedzi.

\section{Wyniki badań i omówienie}

Większość ankietowanych (77,5\% Polaków i 60\% Ukraińców) uprawiało ziemniak w swoim gospodarstwie. Zdecydowanie mniej osób z obydwu krajów nie posiadało gospodarstwa $\mathrm{i}$ nie prowadziło tej uprawy, mieszkali w mieście i nabywali ziemniaki z różnych źródeł.

W Polsce największa liczba respondentów stwierdziła, że spożywają bulwy ziemniaka 1-2 razy w tygodniu (40\%), nieco mniej osób (30\%) zadeklarowało spożycie 3-4 razy w tygodniu, a codzienne spożycie zadeklarowało jedynie 10\% ankietowanych osób. Mieszkańcy Ukrainy preferowali spożywanie 3-4 razy w tygodniu (30\%), częstotliwość $1-2$ razy w tygodniu zadeklarowało $27,5 \%$ badanych, a spożycie $1 \mathrm{raz}$ w tygodniu jedynie 17,5\% osób. Zależności te nie były statystycznie istotne.

Następnie ankietowanym postawiono pytanie o formę, w jakiej najczęściej spożywają ziemniaki: gotowane $\mathrm{z}$ wody, pieczone, smażone/prażone, przetwory sporządzane z bulw 
(rys. 1). Największą popularnością, zarówno wśród mieszkańców Ukrainy (57,5\%) jak i z Polski (40\%) cieszyły się ziemniaki gotowane z wody we własnym domu. Natomiast najmniej respondentów $\mathrm{z}$ obydwu krajów konsumowało przetwory ziemniaczane (odpowiednio 5\% i 10\%), co mogło wynikać z dość wysokiej ceny frytek i chipsów w porównaniu do gotowanych bulw. Polacy chętnie spożywali ziemniaki zarówno w formie pieczonej (25\%) jak i smażonej (25\%), natomiast mieszkańcy Ukrainy bardziej upodobali sobie formę pieczoną $(27,5 \%)$ niż smażoną $(10 \%)$. W tym przypadku również nie stwierdzono statystycznie istotnej zależności pomiędzy omawianymi zmiennymi.

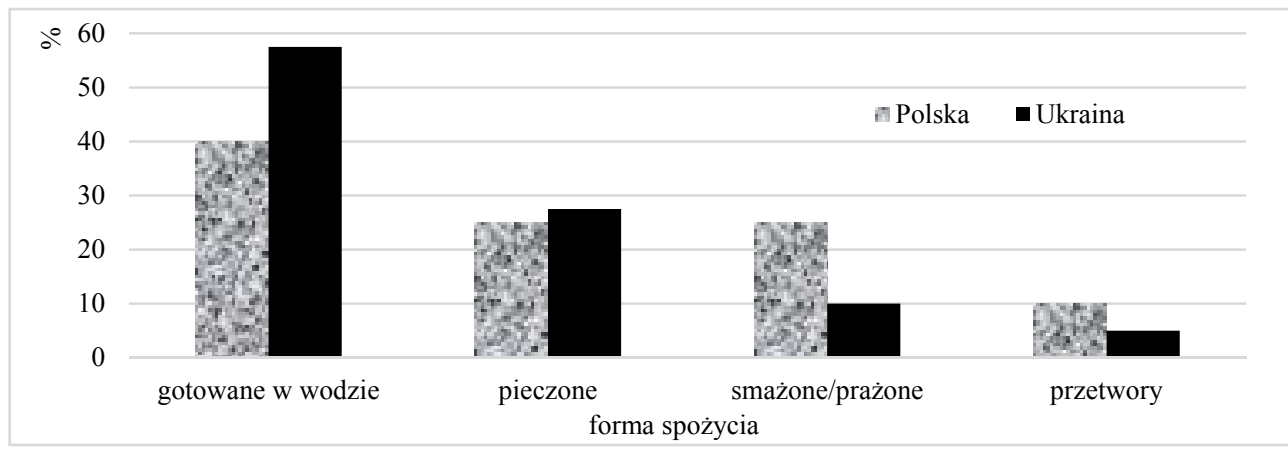

Rys. 1. Forma spożycia ziemniaka deklarowana w badaniach ankietowych

Fig. 1. Form of potato consumption indicated in the survey

Źródło: opracowanie własne na podstawie badań ankietowych.

Na wybór miejsca zakupu ziemniaków wpływa wiele czynników: cena, jakość, czy odległość miejsca zakupów. Kolejne pytanie podano w formie zamkniętej: w sklepie osiedlowym, w supermarkecie, na bazarze, posiadam własne gospodarstwo lub z innego źródła (rys. 2). Odpowiedzi były zgodne z wynikami wskazującymi, że $50 \%$ respondentów z Ukrainy i 40\% z Polski posiadało własne gospodarstwo lub działkę, które dla tych osób były źródłem pozyskiwania bulw ziemniaka do celów konsumpcyjnych. Na bazarze kupowało ziemniaki $20 \%$ osób z Ukrainy i 30\% z Polski. Najmniej mieszkańców Ukrainy nabywało je w supermarketach i w sklepach osiedlowych - po $15 \%$. Natomiast Polacy najrzadziej odwiedzali sklepy osiedlowe i supermarkety, odpowiednio było to $10 \%$ i $20 \%$ ankietowanych (rys. 2). Struktura handlu detalicznego w obydwu krajach jest podobna. Nie udowodniono statystycznie istotnej zależności preferowanego miejsca zakupu i kraju zamieszkania respondentów. 


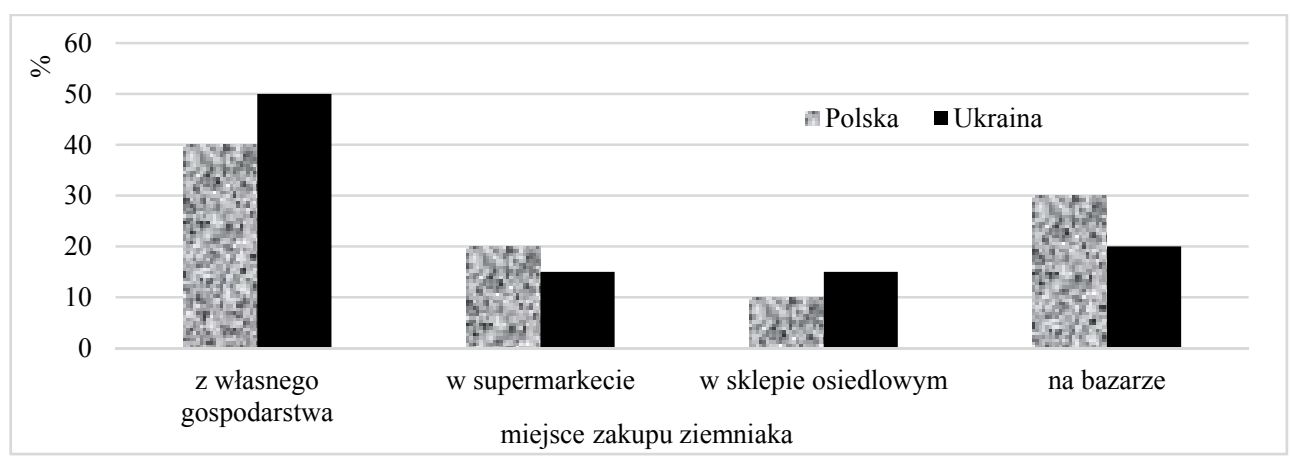

Rys. 2. Miejsce zakupu ziemniaka deklarowane w badaniach ankietowych

Fig. 2. Potato purchase place indicated in the survey

Źródło: opracowanie własne na podstawie badań ankietowych.

Zarejestrowane, a następnie będące w sprzedaży odmiany ziemniaka pochodzą z różnych krajów, m.in. z Polski, Ukrainy, Niemiec, Holandii i Francji. Import ziemniaków nieprzetworzonych (sadzeniaki, odmiany wczesne i z jesiennego zbioru) na polski rynek w latach 2013-2015 wynosił 134-206 tys. ton. Prognozuje się, że w najbliższych latach import nie ulegnie większym zmianom (Rynek ziemniaka..., 2016). Import ziemniaków na Ukrainie, jak wynika z wywiadu bezpośredniego, jest zdecydowanie mniejszy, a ziemniaki pochodzą głównie z Polski i Niemiec. Warunki hodowli i uprawy oraz ich wygląd i jakość w poszczególnych krajach są zróżnicowane. Interesująca była możliwość uzyskania odpowiedzi na pytanie, czy respondenci zwracali uwagę i czy przy zakupie sugerowali się krajem pochodzenia? Czy jest to ważna opinia dla kupujących? Spośród ankietowanych aż $45 \%$ Polaków i 65\% Ukraińców nie interesowało się krajem pochodzenia nabywanych bulw ziemniaka. Natomiast 35\% mieszkańców z Ukrainy i 55\% z Polski zwracało uwagę na kraj, z którego pochodził Solanum tuberosum. Jednak zależności te nie były statystycznie istotne. Zainteresowanie krajem pochodzenia bulw ziemniaka nie miało istotnego związku z krajem zamieszkania ankietowanych.

Kolejne pytanie dotyczyło zainteresowania kupujących etykietą na opakowaniu kupowanych ziemniaków, zwłaszcza paczkowanych, a sprzedawanych najczęściej w dużych sklepach i supermarketach. Wyniki badań wskazały, że tylko $25 \%$ osób z Ukrainy było zainteresowanych etykietą przy ziemniakach paczkowanych, natomiast zdecydowanie więcej - 75\% mieszkańców Polski czytało etykietę, żeby zgłębić informacje o bulwach przeznaczonych do konsumpcji. Przedstawione zależności miały charakter wysoce istotny (chi kwadrat $=11,79$ przy $p=0,0006$ ). Należy podkreślić, że sieć supermarketów w Polsce jest lepiej rozwinięta niż na Ukrainie, a zatem ziemniaków konfekcjonowanych na polskim rynku jest zdecydowanie więcej niż na rynku ukraińskim, na którym przeważa sprzedaż bulw luzem.

Następne pytanie dotyczyło cech, na które respondent zwracał uwagę w czasie zakupu bulw ziemniaka. Do wyboru były: dostępność ceny, odmiana, dobry wygląd zewnętrzny, opakowanie i wielkość bulw. Najwięcej ankietowanych z Ukrainy zwracało uwagę na niską cenę $-13 \%$ odpowiedzi, a najmniej na opakowanie $-2 \%$, na etykietę $10 \%$ odpowiedzi, na wielkość ziemniaka 15\%, na dobry wygląd zewnętrzny i odmianę 21\% i 19\%. W przypadku $29 \%$ odpowiedzi udzielonych przez respondentów z Polski najważniejsza była etykieta, $21 \%$ 
odpowiedzi dotyczyło dobrego wyglądu zewnętrznego, 20\% dotyczyło odmiany, 19\% wielkości bulw, $14 \%$ ceny, natomiast opakowaniem respondenci nie byli zainteresowani. Omówione zależności nie były statystycznie istotne (rys. 3). Badania Mozolewskiego i in. (2014) wykazały, że polscy konsumenci dokonując zakupu nie preferowali konkretnej odmiany (63\%) i najczęściej nabywali ziemniaki luzem w sklepie warzywniczym (66\%), a znacznie mniej badanych wybierało bulwy opakowane w siatkę z tworzywa sztucznego (27\%). Natomiast zdaniem Chotkowskiego i Rembezy (2005) wraz ze zmianami stylu życia, wzrostem dochodów, poziomem wykształcenia konsumenci będą skłonni zapłacić wyższą cenę za dobry jakościowo produkt, odpowiednio przygotowany i opakowany.

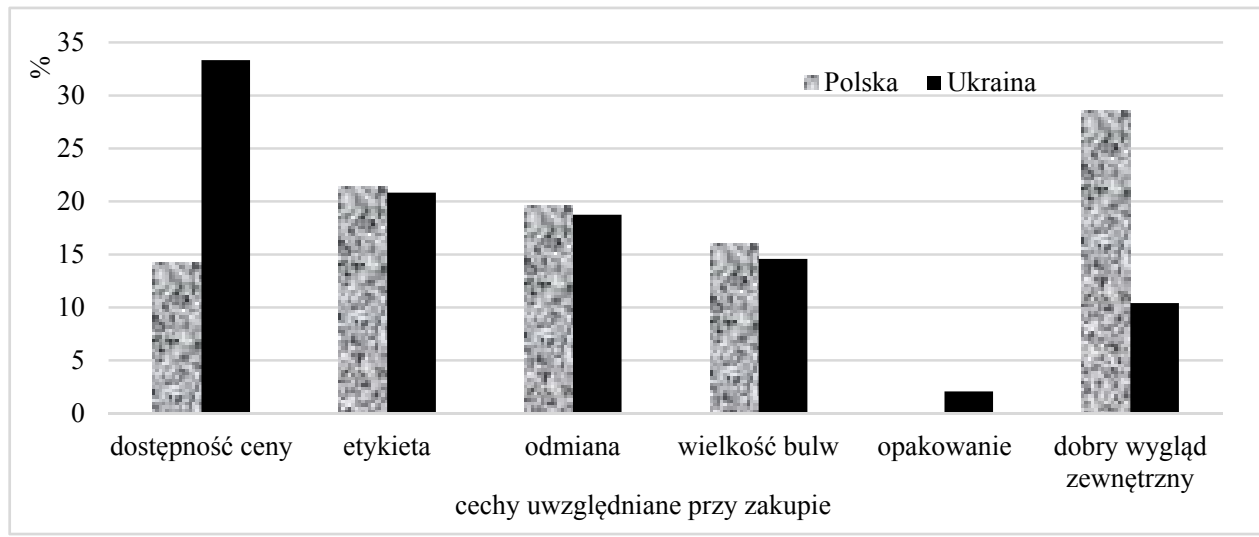

Rys. 3. Cechy, na które respondenci zwracali uwagę w czasie zakupu bulw ziemniaka deklarowana w badaniach ankietowych

Fig. 3. Characteristics to which respondents paid attention while purchasing potato tubers indicated in the survey

Źródło: opracowanie własne na podstawie badań ankietowych.

Ankietowani, pochodzący z obu krajów, najbardziej doceniali w ziemniaku dobre walory smakowe (po $28 \%$ odpowiedzi). Dla polskich konsumentów ważna również była wielkość bulw ( $26 \%$ odpowiedzi) oraz dobry wygląd zewnętrzny (19\% odpowiedzi). Dla konsumentów z Ukrainy w dalszej kolejności ważna była niska cena $(21 \%)$ i dobry wygląd zewnętrzny $(16 \%)$. Wszyscy udzielające odpowiedzi za najmniej ważne uznali dobre przechowywanie ziemniaka w miejscu zakupu. Niewiele też osób (7\% i 11\%) zwracało uwagę na zawartość witaminy $\mathrm{C}$, która obok zawartości skrobi i białka, jest jedną z ważniejszych cech jakościowych bulw jadalnych (Leszczyński, 2012; Zgórska 2013a,b; Zarzecka i in., 2013) (rys. 4). Wielkość plonu nie miała bezpośredniego wpływu na decyzje zakupowe, natomiast wpływała pośrednio poprzez kształtowanie cen. 


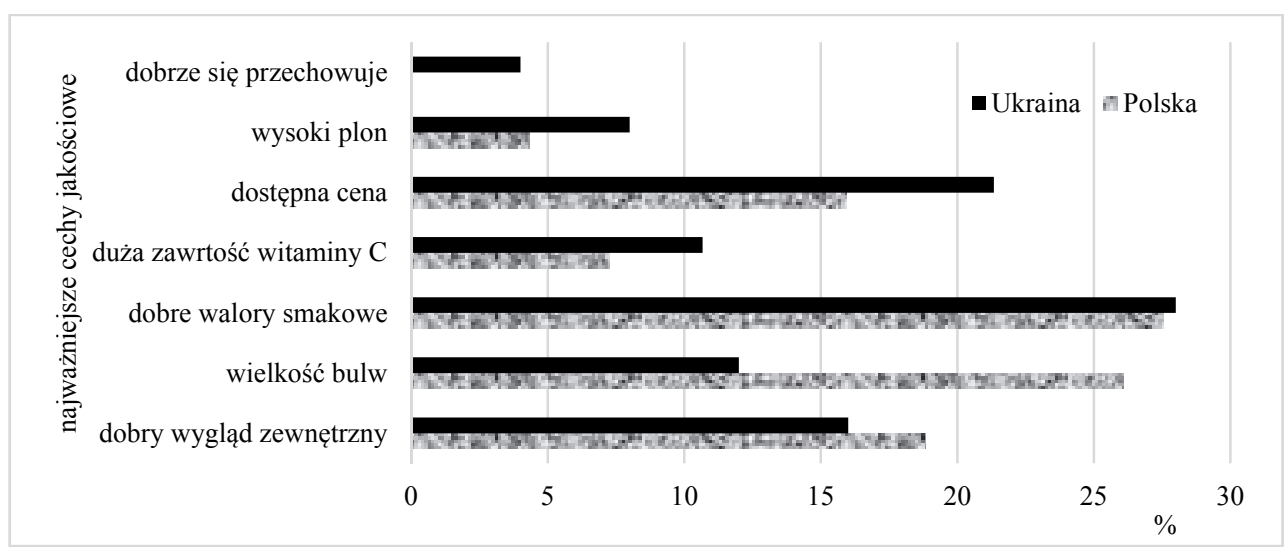

Rys. 4. Najważniejsze cechy jakościowe wskazane przez respondentów w badaniach ankietowych

Fig. 4. The most important qualitative characteristics indicated by the respondents in the surveys Źródło: opracowanie własne na podstawie badań ankietowych.

Ostatnie pytanie stanowiło krótkie podsumowanie wywiadu, a dotyczyło ono oczekiwań respondentów przy zakupie bulw ziemniaka.

Przedstawione dane wskazują, że Ukraińcy i Polacy najbardziej oczekiwali bulw o dobrej jakości kulinarnej (odpowiednio 50\% i 65\%) i o dobrym wyglądzie zewnętrznym (35\% i $25 \%)$. Zdecydowanie mniejsze wymagania ankietowanych, pochodzących z obydwu krajów, dotyczyły „bogatej” w informacje etykiety i niskiej ceny (rys. 5). Etykieta/oznakowanie powinna zawierać: cenę, nazwę odmiany, masę netto, kraj pochodzenia, dane przedsiębiorcy i typ konsumpcyjny (Mozolewski i in., 2014).

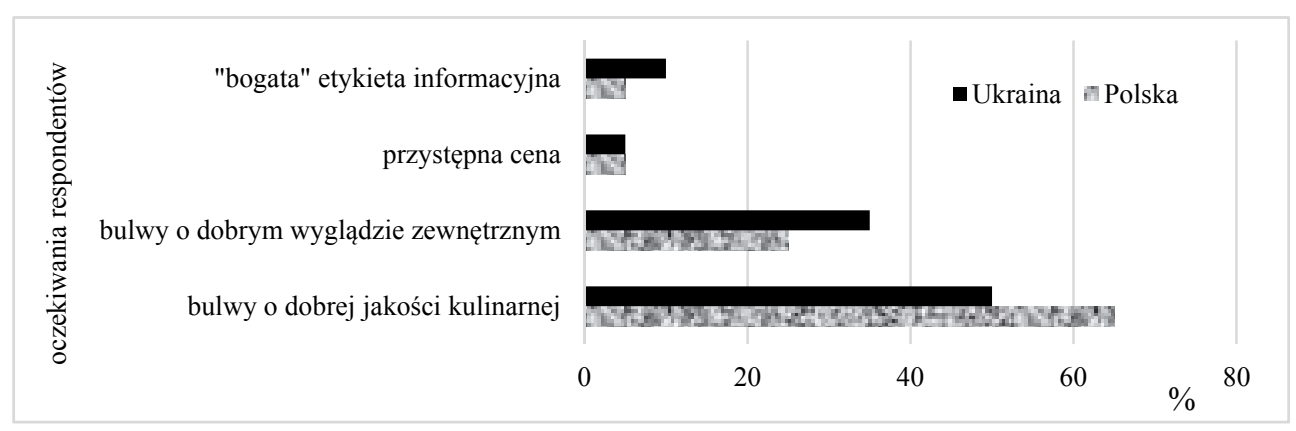

Rys. 5. Oczekiwania respondentów przy zakupie bulw wskazane badaniach ankietowych

Fig. 5. Respondents' expectations when purchasing tubers indicated in the survey

Źródło: opracowanie własne na podstawie badań ankietowych. 


\section{Podsumowanie}

Ziemniak jest jednym $\mathrm{z}$ ważniejszych gatunków roślin rolniczych uprawianych w Polsce, na Ukrainie, krajach Unii Europejskiej i niemal we wszystkich krajach świata. Zajmuje ważną pozycję w jadłospisie człowieka, gdyż jest niskokaloryczny oraz wyróżnia się wysoką wartością odżywczą, dietetyczną i zdrowotną. Ziemniak to także surowiec wykorzystywany wielostronnie: przeznaczany na paszę, w przetwórstwie spożywczym oraz w licznych gałęziach przemysłu, a jednocześnie stanowi jedną $\mathrm{z}$ najlepszych roślin przedplonowych dla roślin uprawnych. Jest to wręcz roślina uniwersalna, a jej bulwy z jednostki powierzchni dostarczają więcej energii i białka niż inne rośliny rolnicze (Leszczyński, 2012; Zarzecka i in., 2013; Zgórska, 2013a).

Przeprowadzone badania wykazały, że na Ukrainie codzienne spożywanie ziemniaków jest powszechniejsze niż w Polsce. Respondenci z Ukrainy nie zwracali większej uwagi na etykietę i kraj pochodzenia bulw ziemniaka, natomiast Polacy byli zainteresowani krajem pochodzenia i etykietą informacyjną przy zakupie bulw paczkowych. Do najważniejszych cech, które wyróżnili Ukraińcy należały: cena, dobre walory smakowe, natomiast Polacy preferowali w ziemniaku dobry wygląd zewnętrzny i wielkość nabywanych bulw. Konsumenci z obydwu krajów oczekiwali przy zakupie bulw o dobrej jakości kulinarnej. Również Mozolewski i in. (2014) stwierdzili, że większość respondentów przy wyborze ziemniaków kierowała się przede wszystkim cechami konsumpcyjnymi bulw i posiadali oni znaczną wiedzę o ich wartości odżywczej.

\section{Literatura}

Camire, M.E., Kubow, S., Donnelly, D.J. (2009). Potatoes and human health. Critical Reviews in Food Science and Nutrition, 49(10), 823-840.

Chotkowski, J., Rembeza, J. (2005). Preferencje konsumentów i zmiany w spożyciu ziemniaków. Roczniki Naukowe Stowarzyszenia Ekonomistów Rolnictwa i Agrobiznesu, 7(3), 42- 49.

Домбровська, С.С. (2015). Споживання плодоовочевої продукції в україніу контексті забезпечення продовольчої безпеки країни. Розділ 2. Економіка та управління національним господарством. (Spożycie owoców i warzyw na Ukrainie w kontekście bezpieczeństwa żywnościowego kraju). 20(3), 37-40.

Gawecki, J., Hryniewiecki, L. (2010). Żywienie człowieka. T 1. Wyd. PWN, Warszawa.

Grużewska, A., Zarzecka, K., Gugała, M., Paprocka, S. (2016). Produkcja i znaczenie konsumpcyjne ziemniaka i rzepaku w Polsce i w wybranych krajach UE. Zeszyty Naukowe SGGW. Problemy Rolnictwa Światowego, $16(2), 85-93$.

Herse, J. (1980). Szczegółowa uprawa roślin. Wyd. PWN, Warszawa.

Kunachowicz, H., Nadolna, I., Iwanow, K., Przygoda, B. (2010). Wartość odżywcza wybranych produktów spożywczych i typowych potraw. Wyd. Lekarskie PZWL, Warszawa.

Leszczyński, W. (2012). Żywieniowa wartość ziemniaka i przetworów ziemniaczanych (Przegląd literatury). Biuletyn IHAR, 266, 5-20.

Lista opisowa odmian. Rośliny rolnicze. Cz. 2. (2015). Wyd. COBORU, Słupia Wielka.

Mozolewski, W., Radzymińska, M., Łazicki, T. (2014). Jakość ziemniaka spożywczego w opinii konsumentów. Biuletyn IHAR, 272, 5-16.

Nowacki, W. (2015). Szanse i zagrożenia rynku ziemniaka w Polsce. Roczniki Naukowe Stowarzyszenia Ekonomistów Rolnictwa i Agrobiznesu, 17(1), 169-175.

Nowacki, W. (2016). Rynek ziemniaków jadalnych w Polsce - stan obecny i perspektyw rozwoju. Roczniki Naukowe Stowarzyszenia Ekonomistów Rolnictwa i Agrobiznesu, 18(1), 196-201.

Рудь, В.П., Муравйова, О.В., Сидора, В.В. (2015). Проблеми розвитку ринку картоплі в Україні. (Problemy rynku ziemniaków na Ukrainie). Овочівництво і баштанництво. Вип. 61, 193-199.

Rynek ziemniaka. Stan i perspektywy. Analizy rynkowe. (2015). Wyd. IERiGŻ-PIB, ARR, MRiRW, Warszawa, 42, 1-37. 
Rynek ziemniaka. Stan i perspektywy. Analizy rynkowe. (2016). Wyd. IERiGŻ-PIB, ARR, MRiRW, Warszawa, $43,1-37$.

Sołtys, D. (2013). Solanina i chakonina - główne glikoalkaloidy ziemniaka uprawnego (Solanum tuberosum L.). Kosmos, 62(1), 129-138.

Statystyczny Rocznik Ukrainy. (2015). Рослинництво Кіровоградськоїобласті у 2015 році. Kiev, 116-143.

Stypa, I., Zgórska, K. (2010). Ziemniak nasz powszedni. Wyd. IHAR, Bonin.

Wierzbicka, A. (2012). Zawartość składników mineralnych w bulwach ziemniaka uprawianego w systemie ekologicznym, ich wartość żywieniowa i wzajemne relacje. Journal of Research and Applications in Agricultural Engineering, 57(4), 188-192.

Wynikowy szacunek produkcji głównych ziemiopłodów rolnych i ogrodniczych w 2015 roku. (2014). GUS, Warszawa.

Zarzecka, K. (2009). Potato as a global plant nutritional dietary and medicinal values. Rozprawy Naukowe PWSZ im. Jana Pawła II, Biała Podlaska, 3, 163-175.

Zarzecka, K., Gugała, M. (2010). Jakość konsumpcyjna bulw ziemniaka jadalnego w sieci handlowej Siedlec i Międzyrzeca Podlaskiego. Roczniki Naukowe Stowarzyszenia Ekonomistów Rolnictwa i Agrobiznesu, 12(4), 403-406.

Zarzecka, K., Gugała, M., Zarzecka, M. (2013). Ziemniak jako dobre źródło składników odżywczych. Postępy Fitoterapii, 3, 191-194.

Zgórska, K. (2013a). Wykorzystanie ziemniaka do celów spożywczych i przemysłowych. Inżynieria Przetwórstwa Spożywczego, 3(7), 5-9.

Zgórska, K. (2013b). Ziemniak jako składnik racjonalnej diety. Ziemniak Polski, 1, 29-35.

Zhu, F., Cai, Y.Z., Ke, J., Corke, H. (2010). Compositions of phenolic compounds, amino acids and reducing sugars in commercial potato varieties and their effects on acrylamide formation. Journal of the Science of Food and Agriculture, 90(13), 2254-2262.

Wyniki badań zrealizowane w ramach tematu badawczego $\mathrm{nr}$ 214/S/04 zostały sfinansowane z dotacji na naukę, przyznanej przez Ministerstwo Nauki i Szkolnictwa Wyższego. 